\title{
The Effect of Unified Globalised Corporate Social Responsibility Strategy on Customer Loyalty
}

\author{
Kamaldeep Singh ${ }^{1, *}$ \\ ${ }^{1}$ Turiba University, department of business administration, 68 Graudu Street, Riga \\ LV-1058, Latvia
}

\begin{abstract}
.
Research Background: In this modern world, every person needs a specific medium of information in order to survive with the communication means which is effectively and easily answered by the means of telecommunication. In this fast and rapidly moving world, the telecommunication sector has become a main tool to share and communicate information from one end to another. It bridges the gap between people irrespective of cities, countries or continents. During such modern and fast paced telecommunication times, a well devised customer social responsibility is known as catalyst that can significantly elevate the business operations for any telecommunication organizations in this sector. In order to advance in this rapidly growing technical market every telecommunication company is trying to maintain strong relationships with the customers in order to provide better service quality and develop new market strategies. The author suggests that telecommunication service providers must work on customer social responsibility strategies and policies that immensely reflects a significant impact towards customer loyalty.

Purpose of the article: To examine that how corporate social responsibility in lieu with service quality and customer satisfaction affects the customer loyalty in telecommunication sector. This article also highlights the customer behaviour towards CSR policies and what significance value added services have on the customer accordingly.

Methods: The author used descriptive statistics employed to analyse survey. Based on the finding the author has prepared the analysis and result.

Finding \& Value added: Implementing the CSR practice that is corporate social responsibility and better customer service quality, a telecommunication company can increase customer loyalty.
\end{abstract}

Keywords: Customer; Telecommunication; Loyalty; CSR

JET Classification: $J 28 ; J 29 ; M 43 ; M 14$

${ }^{*}$ Corresponding author: kampreet0001@gmail.com 


\section{Introduction}

Corporate social responsibility: In modern times, corporate social responsibility presents a model and strategy that helps in regulating business and its activities, furthermore it also can help in maintaining a stronger bond between employees and corporation. In this competitive market, service quality and product quality may not be enough to impact customer loyalty, besides every company needs to survive and find new ways to stay ahead in the market competition. Corporate social responsibility is a possible way that increases and influences the corporation's association. Because corporate social responsibility maintains a strong relationship with both internal reasons (customer and employee) and external reasons (Local Communities). Corporate social responsibility plays a significant role in telecommunication sector, as customers are becoming more aware of the corporate behaviour it is equally important for the telecommunication companies to incorporate the best (CSR) policies, strategies, and principles for the long term vision, mission and its goals. Nowadays it is becoming equally complicated for the companies to be in this competitive market without proper (CSR) strategies to count or rely upon, such CSR strategies apart from economical perspectives are core heart towards customer service quality which is equal to customer satisfaction that leads to customer loyalty eventually.

\section{Corporate Social Responsibility: Literature Review}

According to (Yazidi, April 2020) the author has conducted a study in relationship between Corporate Social Responsibility activities and customer satisfaction and customer loyalty. In this research work, the author describes that corporate social responsibility activities (CSR) do not affect significantly on the customer loyalty. However, it suggests that the customer's attitude and its behaviour does not gets affected in CSR activities by the company. The research indicates that there is a good possibility that there can be another factor that might influence the customer loyalty such as services quality. The author further examined that CSR may be a strength and guarantee for customer loyalty but CSR however, does not significantly affects the customer loyalty. Another result shows that corporate social responsibility posts a positive effect on customer satisfaction. The results that are defined show that CSR practice with its dimensions might improve customer satisfaction. The result is supported by the claim that customer satisfaction significantly effects on the loyalty procedure. The author further in his study shows the impact of corporate social responsibility on the customers. It is defined that how determinants, moderators and mediators attain customer loyalty. The results show that customer satisfaction, builds customer trust. The corporates try to maintain and mediate the mechanisms of the relationship between corporate social responsibility, and customer loyalty. Additionally, strong strengthens of CSR have a significant effect on the customer loyalty. The author (Chinda, 27-Feb-2020) defines that the relationship between service quality and customer loyalty in the telecommunication industry in Lagos State, Nigeria. The author used Service Quality Parameters such as network quality, Value-added services, price structure and customer service and customer loyalty and implied the use of two parameters behaviour and attitude. In this study it is observed that that service quality has significant relationship with customer loyalty. On this study-specifics it can be defined that network quality and price structure and customer service have a strong and significant relationship between behaviour and attitudinal loyalty in the telecommunication industry. However, is can also be accepted that the value-added services do not hold a significant relationship with behavioural loyalty but a significant relationship with attitudinal loyalty in the telecommunication sector. (Kumar, 2018) the author examined the study and the effect of service quality dimensions on customer loyalty and customer satisfaction in telecommunication sector. The author in this study defined five dimensions of service quality, 
the results show that in the telecommunication sector it does not affect all the service quality dimensions. The research further highlights that only empathy and reliability have a significant effect on customer satisfaction. On the other hand, the author defined empathy, assurance, responsiveness, and tangibility to have significant effect on customer loyalty. (Ting, 3 November 2020) the author explained that customer satisfaction and customer trust is positively affected by network quality and the corporate image. On the behalf of network quality and corporate image, customer loyalty automatically influences the telecommunication sector. The other perspective suggests that trust and satisfaction acts and mediate the relationship between network quality and loyalty as well as a relationship between corporate image and customer loyalty. (Mbug, March 2018) the author examines the study relationship between customer experience and customer loyalty in the telecommunication sector. It is observed that there are three-factor such as (Service, charging and branding) which plays an important role in the telecommunication industry. In other words, a distinct core service maintains the greater customer experience which creates cementing customer loyalty in the telecommunication industry. In short, customer loyalty will increase and improve customer relationship and customer experience as well. (Hapsari, 13 Jan 2020) the author in this research focuses that customer engagement (customer relation) and trust has a direct and significant effect on customer loyalty. In other words, the author defines that service fairness and customer trust have played a significant role to effect customer loyalty in the telecommunication sector. (Raf, June 2020) the author has explained loyalty programs in his study. The study highlights that customer satisfaction and loyalty programs play a major role to create the customer loyalty in telecommunication sector. Customer satisfaction has created a middle role in the relationship between customer loyalty and loyalty program. The loyalty program has significant effect and influence on customer satisfaction. (Ibrahim Harazneh, 2020) the author explains that service quality and customer satisfaction has both positive effect on customer loyalty in Jordanian telecommunication sector. The author also explains that the moderator model that is (switching cost) has a positive effect on enhancing the relationship between customer satisfaction and service quality for increasing the customer loyalty in the telecommunication sector. (Sahin, April 2020) the author explains that in the telecommunication industry, the technical quality of services has more impact on trust and loyalty. It is also observed that functional quality has indirect impact on loyalty and trust. (Chee, June 2019,) the author describes that network, customer services and pricing structure has Major effect on the customer satisfaction and also explained that billing system and value-added services does not influence the customer satisfaction however, customer satisfaction has a positive impact on customer loyalty.

\section{The relationship of CSR, Service Quality and Customer Satisfaction is equal to Customer Loyalty}

Many Researchers have presented and tried to explain the relationships between CSR and customer loyalty within different industries. The Telecommunication sector is also part of the service industry. The previous study attempts to the explain relationship between Corporate Social Responsibility (CSR) and Customer Loyalty (CL) through different types of services. (Moisescu, 2015, p. 21) The study highlights and showcased the facts that CSR policies and activities are hugely related to the customer as it is the main foundation and centre part of the business. However, the service quality and fair prices offered to the customer defines that how effective CSR proves to be whilst generating economy for the telecommunication sector. Thus there is a strong relationship between corporate social responsibility and customer loyalty. In the present day, every customer interacts with service quality. Service quality is the way to win customer loyalty. There are many researchers who contributed to service quality. According to (Parasuraman \& Zeithaml, 1985), they defined 
that the implication in the service sector presents the service quality with global opinion and way. The service quality model which present two factor, for example, functional quality and technical quality. In other words, functional quality service is related to process and Technical quality service is related to outcome of the services. Therefore, it is important to keep the balance when offering high number of services with repetitive and better service quality over and over which eventually enhances the skills and process. It also gives the firm a potential to earn more profitability by the zero abandonment of customer. (Blery et al) suggested that the company or organisation can get behavioural benefits by service quality which enhances the positive good communication and recommendation regarding the customer. According to Blery a service quality is an attitude because customer satisfaction depends upon the service quality attitude of the company and organisation. The author narrates that on the behalf of the service quality, the customer has two option (agree and disagree) regarding the company and organisation. Their opinion that customer behaviour is the middle point between service quality and profitability of the organisation and company. Customer behaviour increase by better service quality of the organisation and company. (Ghotbabadi \& Ramezani, 2015) focus on the environment quality of the organisation proved that customer perception increase by service quality. According to (Ghotbabadi \& Ramezani, 2015, pp. 267-286) it is discussed that a strong relationship between service quality and customer loyalty, attributes to a positive impact on customer satisfaction, hence it can be assumed that customer satisfaction positively enhances the customer loyalty and vice-versa. (Idris et.al, 2017) states that in the telecommunication sector service quality attributes such as Tangible and responsiveness are directly impacted in the customer loyalty.

Customer satisfaction is assumed by the quality of the product, buying process, and, customer retention about the product. Many researchers have focused on customer satisfaction. According to (Dominic \& Guzzo, 2010) customer satisfaction depend upon when the customer feels that their expectations and requirements are completely fulfilled. Customer satisfaction is realized on the behalf of the product and services. In the present time, the main activity of marketing to satisfaction of customer and seller are focused on what a customer are needs. Telecommunication companies increase their users and level of sales by offering better network service and fulfilling other requirements to which a customer is satisfied. (Gul, 2014) states that satisfaction comes out after using the product and service. Customer satisfaction play the important role in marketing which presents the product value and company goodwill. According to the author there is a direct relationship between customer satisfaction and customer loyalty. If the customer is satisfied regarding the product, the customer buying pattern would turn out to be recurring which will correlate to customer loyalty and eventually increase in sales and customer satisfaction.

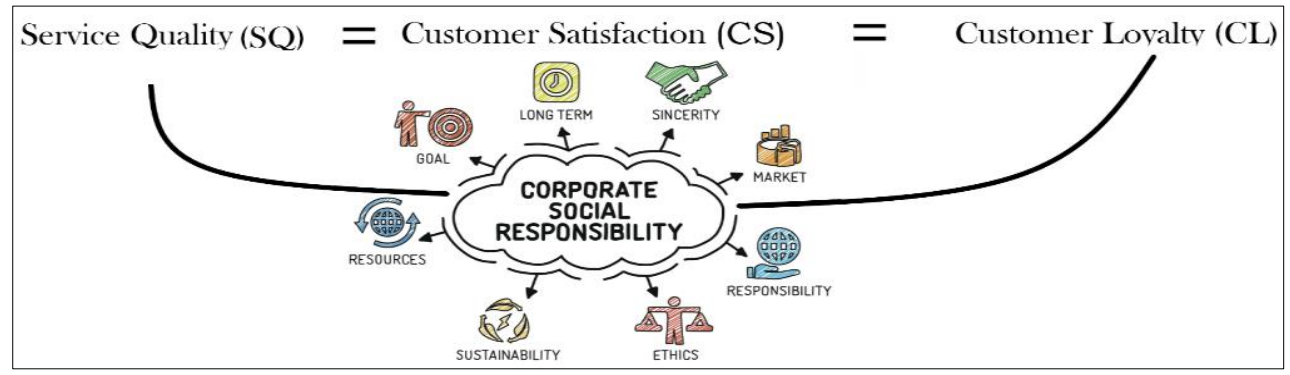

Figure 1, CSR and its relation to SQ, CS \& CL (developed by the author)

According to figure 1, the author tries to highlight how service quality is equal to customer satisfaction that leads to customer loyalty, whilst being governed by CSR that is corporate 
social responsibility. The relationship of customer satisfaction highly depends upon the service quality rendered and combined together it gives a loyal and satisfied customer, however having said that the CSR is the core towards the relationship as CSR's job is not only is to achieve satisfied and loyal customer and retain them but it also focuses achieving that whilst it takes care of all the attributes shown in the figure 1 that is Goal, Long Term, Sincerity, Market, Responsibility, Ethics, Sustainability, and resources

1. CSR (Goal): The author suggests that CSR's goals are framed in the core towards attaining customer loyalty, therefore framing the goals the telecommunication companies nowadays have to consider CSR as long term principle rather than a short burst of bubble.

2. Long Term: As mentioned above CSR is designed in the view of aiming the goals and unless it is not long term it would not benefit either way.

3. Sincerity: A well valued CSR principle and strategy will only be viable if it is in its most sincere form, towards its customers and employees holding no discrepancies.

4. Market: CSR is framed considering various markets and market trends it is definitely designed for long term but needs to be flexible with the marker fluctuations and competitions as well as offerings.

5. Responsible: An effective CSR should be self-regulating as well as accountable towards its customer's dissatisfaction and loyalty index drop or rise.

6. Ethics: The relationship of service quality towards customer satisfaction in order to achieve customer loyalty highly depends upon the CSR's ethics. The ethics should be truly professional towards customers and the competitors, such ethics that are designed to serve its customers and stakeholder and employees not to merely dupe the customers with bluff market campaigns or advertisements.

7. Sustainability \& Resources: The modern day customer is getting very learned, new government rules are emphasising that the companies must involve sustainability factors into their products and services in order to retain a customer its equally important the CSR policies are designed in a sustainable way and that they do not harm the natural resources or deplete them during the course of business.

\section{Research Methodology}

In order to carry out the research the author took a survey for random sampling of. A questionnaire was prepared and distributed to random people that are connected with telecommunication means such as cell phone users etc. A total of 100 respondents where approached from various nations, like India, Europe and other parts of the world. The answers from the survey helped in deriving conclusions and finding for this particular article and highlights the theme selected. The data analysis has been done in descriptive statistical pattern from the feedback received by 80 respondents out of 100 approached. The data received further gives a statistical overview of the customer's preferences and choices in terms of customer relationship and satisfaction with prominent emphasis on customer loyalty as well as customer social responsibility relation (CSR).

\section{Issues put forth:}

Issue 1: During this current time, it's important for the companies to indulge in Corporate Social Responsibility (CSR) for its customers. 


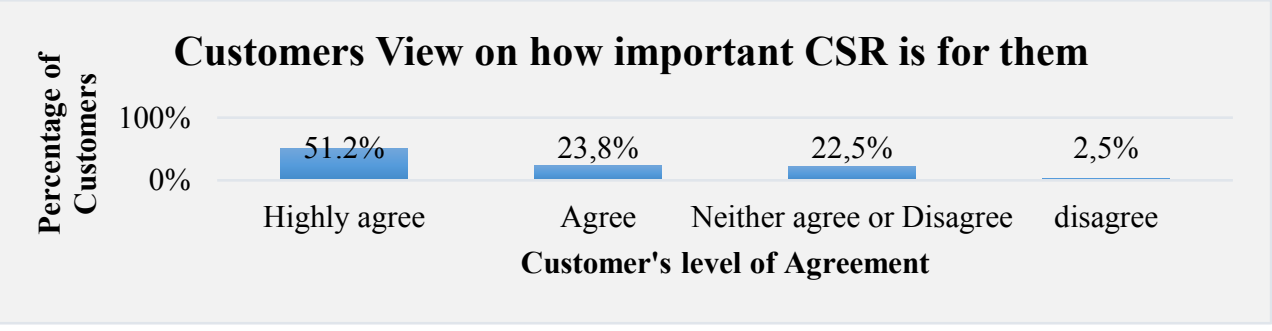

Figure 2 Significance of CSR in Customers decision making (Source as per the survey data collected by author)

\section{Data analysis:}

The above mentioned figure 2, clearly highlights that more than $75 \%$ of the customers in the form of respondents agree that (CSR) is a very important tool in terms of customer loyalty and brand hostage. It does not only build the image of the company but also creates a bond with which the customer turns out to be loyal too. This does not only benefit the customer but it's an equally important tool for the company's progress and customer retention. Another $22 \%$ are still not aware and could not focus a decision that can impact their buying power towards services, these are the customers who are still naïve or new towards the service industry network. Perhaps, it can also be assumed that these $22 \%$ of the customers have not experienced the service industry's impact on their usual life as they are just beginners as the users of telecommunication services and would eventually consider the fact that CSR is important tool in the service industry specially in telecommunication in the long run when they figure out better and viable options simultaneously. A very small portion that is $2 \%$ disagrees which eventually would be the case in any sector.

Issue 2: Telecommunication service providers should indulge in adapting to innovative CSR strategies

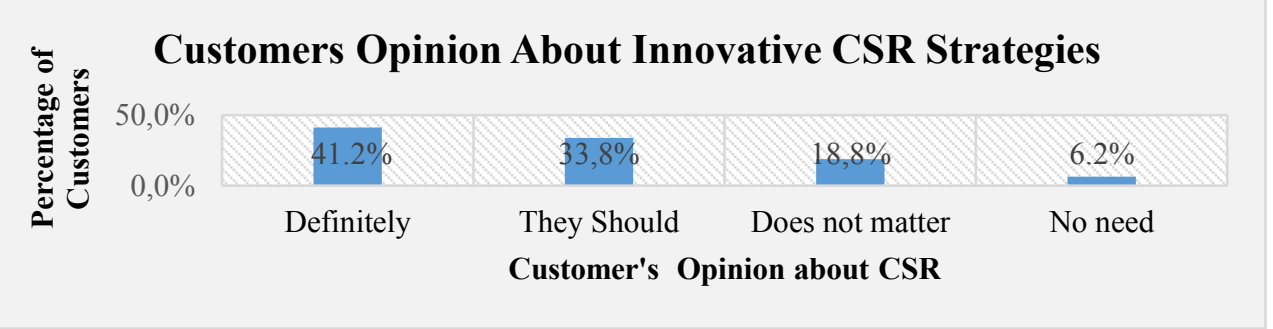

Figure 3 viewpoint on innovative CSR strategies adopted by telecommunication companies (Source as per the survey data collected by author)

\section{Data analysis:}

The above figure 3, highlights that $41 \%$ of customers are of the opinion that the telecommunication companies need to implement innovative CSR strategies for customer loyalty as well as retention and another $33.8 \%$ believe it is necessary as well with this data the author can assume that customers are looking forward for new CSR strategies among the telecommunication companies whereas the telecommunication companies are not focusing much on this regard. If the percentage from the customers are clubbed from definitely agree and they should i.e. $41.3 \%+33.8 \%$ we get a staggering $75.1 \%$ of customers who are of the same opinion. A good amount of customers that is around $18.8 \%$ do not believe it matters to 
them, the author thus assumes these are customers that are least bothered with the CSR strategies which could highly impact them. Another assumption about this percentage is these are the customers who are loyal to their service providers and wouldn't care much to leave them for better options, hence old goodwill compromises of around $18.8 \%$ this can be assumed. However, according to the author it is often seen that any industry has its amount of loyal customers. It is not a hidden fact the service industries have been forever been focusing on catering more improved and better services to their old and loyal customers than to the new ones. The idea is pretty clear the telecommunication industry it is not about the sales but about customer retention once, the company figures out their customers are sticking around for a longer time their services tend to get more modified, flexible, helpful and even lucrative to build a goodwill and customer retention. The benefit of telecommunication industry only depends upon the long term customer plans as seen in many cell-phone communication service providers and hence they tend to focus more on aged customers and according to the authors assumption this $18.8 \%$ are those customer segment. However, the fact to be kept in mind is during this pursuit the telecommunication industries are in a constant battle between retaining old customers and building new long term customer base hence it is necessary to have innovative CSR strategies which suffices both the issues. The author here also points out the CSR innovative strategies are not helpful if they are not combined with the value added service with the same. Together the value added services and CSR can potentially lift the telecommunication service industry to new levels of customer retention as well as brand loyalty. For this regard the author has taken a survey about influence of value added services in a customer's lifestyle, which with percentage is analysed in the figure 3 below subsequently.

Issue 3: Can A Value Added Service Influence the lifestyle of the customer in the telecommunication sector?

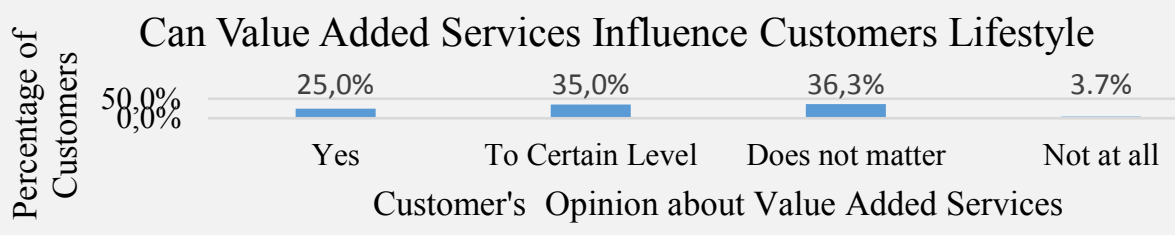

Figure 4 Significance of value added service according to customer's perspective (Source as per the survey data collected by author)

\section{Data Analysis:}

The figure 4, shows the data gathered from respondent customers by the author, it helps in analysing the mind-set of customers towards CSR. It is clearly visible in the above graph that value added services in customer relationship management does not make any impact on the lifestyle of the consumer. Almost $36 \%$ customers believe that value added service (VAS) do not influence their lifestyles in total, thus one can assume that VAS in CSR on one hand does not impact the lifestyle of the consumers but does makes a huge difference in decision making on service procurement accordingly. However, there is an almost equal number of respondents that believe VAS does influence their lifestyle to a certain level, this can be assumed as better services cater more freedom and less stress of service lags and network issues that give customers to live, roam, travel and even work for that matter stress free indirectly influencing their lifestyle. A good 25\% agree completely that VAS in CSR does influence their lifestyle a lot, with which that author can assume that this section of consumers is possibly the younger clientele who are eagerly looking for such value added services, so 
that they could save on pocket and have a good to go package. Usually it is observed younger customers tend to look forward for such services as they are constantly trying to utilize telecommunication channels to its optimum levels which provides value for money in limited budget. A section of almost $4 \%$ show that they are least bothered by such services and henceforth the other can conclude this section is probably the older generation who are not really concerned about the service package than the quality of the network because they are not using or rather utilizing full services of the network providers often.

Issue 4: Are Telecommunication service providers catering different value added services among the competitors?

\title{
CUSTOMER OPINION ABOUT VAS
}

\author{
- Yes provide different VAS \\ Yes but to some extent \\ - They are same with all service providers $₫$ Completely Not \\ Do not Know
}

1

\begin{tabular}{|c|c|c|c|}
\hline $3 \% \quad 16 \%$ & $35 \%$ & $31 \%$ & $15 \%$ \\
\hline
\end{tabular}

PERCENTAGE OF THE CUSTOMERS OPINION

Figure 5. Opinion of the customers if their telecommunication service providers offer different VAS from their competitors (Source as per the survey data collected by author)

\section{Data Analysis:}

The author in figure 5, focuses how customers are reacting to the VAS offered by different telecommunication service providers in the market amongst their competitors. The customer's opinion here is very important as they are the end users of the services. It is clearly seen that $35 \%$ of the customers are of the opinion or belief that all the telecommunication service providers are offering same service packages and VAS when compared to their competitors, again raising the claim to involve more new innovative strategies for CSR and VAS to offer something different. Perhaps a bit of free subscriptions or discounts but nothing more significantly different than each other. However, around same percentage that is $31 \%$ the VAS provided by the competitors is not different at all and becomes equally confusing to choose a service provider for their needs and often tend to go by the feedback from the subscribed user or customer. The interesting statistics here are from the customers who agree that VAS is different by different service providers and customers who think it is not different but same package in a new wrap are very different that is $3 \%$ are of the opinion it is not the same and $16 \%$ believe it is to a certain level different, thus creating a huge gap from not at all to a certain extent again pointing out that telecommunication industries are engaged in CSR and VAS strategies which is gradually making its mark among the customers. A 15\% percent of customers cannot make an opinion and according to the author it is assumed they are first time users and would eventually be contributor to the opinion once they have had their fair share of service experience. 
Issue 5: In today's competitive world is your telecommunication network provider offering you high service quality?

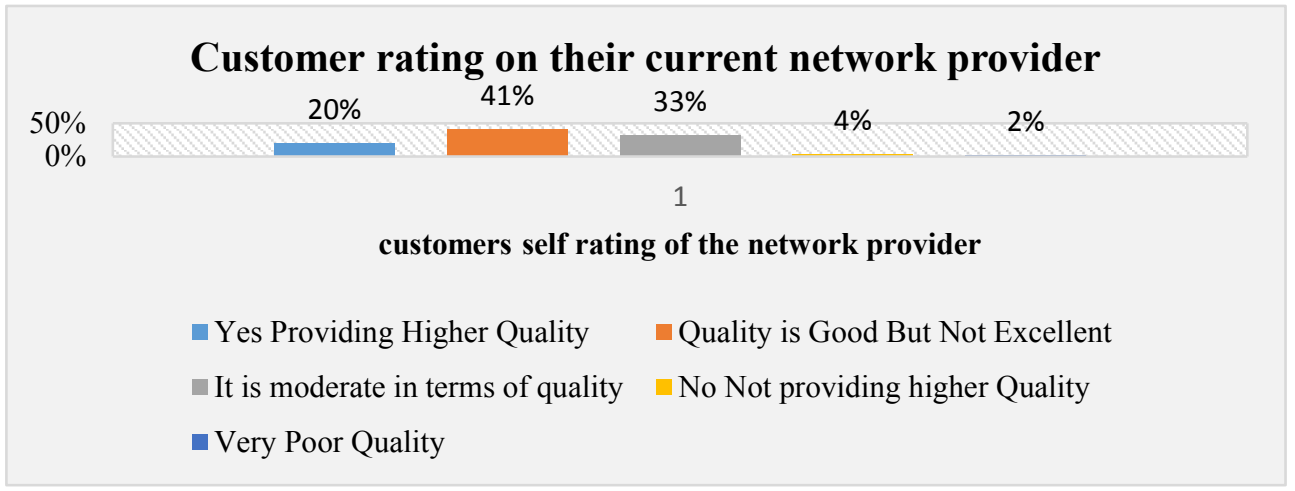

Figure 6. Customers rating their current network provider's service quality (Source as per the data collected by the author)

\section{Data Analysis:}

The authors finding in the figure 6, above clearly highlights that on $20 \%$ of customers are satisfied with their current network service provider's quality. Which again is not good statistics for telecommunication companies catering such services around. Around $41 \%$ customers do not have complains about the quality but are expecting it to be more better and this can probably because of new gadgets or tools, or games or software's rapidly in fluxing the market needing higher speed and connectivity or latency for such operations and often customers find themselves stuck up with lethargic services.33\% of customers believe that quality is not high and is moderate which points out and gives an assumption that these customers must have switched from a better quality network service providers because that is how they can distinguish or relate to the quality standards and often these type of customers can be the ones making the companies better their qualities as to their competitors or would eventually find the newly enrolled customers going back to the same old company back. On the other hand a number of $4 \%$ believe that the current service provider is not providing good quality however they prefer to stick to it, perhaps because there is the sole dominance of that particular company or only presence or not competitors in those remote areas or possibly tieups with other network providers. $2 \%$ are highlighting that the quality is very poor and this segment is often un attended or neglected as their percentage is very low, or perhaps these customers have no other option in the vicinity than the current plan or probably these are customers who have witnessed excellent services before and are just not satisfied with the current one. For this $2 \%$ there can be many reasons to be not satisfied with quality and badging it as very poor quality.

\section{Results}

The author from the above analysis can derive results about (CSR's) impact on a customer as a whole. As per the analysed data it, clearly highlights that more than $75 \%$ of the customers agree that (CSR) is a very important tool in terms of customer loyalty which means customers are aware of the (CSR) and its impact on society, community, company and stakeholders accordingly that is why $41 \%$ of customers are of the opinion that the telecommunication companies need to implement innovative (CSR) strategies to achieve customer loyalty for 
customer loyalty as well as retention. As shown in figure 1, that customer loyalty depends upon the service quality and customer satisfaction. Whereas the data analysis show that a percentage of customers i.e. $36 \%$ customers believe that value added service (VAS) do not influence their lifestyles and since (CSR's) core design principle is to impact all the 7 points such as goal, long term, sincerity, market, responsibility, ethics, sustainability, and resources this $36 \%$ poses a differed value in the current CSR strategies of the network providers from whom the data was collected, thus resulting in poorly designed CSR policies and strategies with immediate attention to improve them, as $36 \%$ is a very big amount to be ignored. Besides this it cannot be over ruled that only $20 \%$ of customers are satisfied with their current network service provider's quality again posing big questions to the current (CSR) strategies of the respondent's network providers simultaneously.

\subsection{Discussions}

In today's communicative world and tough competition on heels, customers are on the brink for companies to lose them to any shaggy or unsatisfactory services. A customer today has plenty of options which he/she didn't have when the telecommunication industry was born! Now the telecommunication industries have to be at the customer's disposal which was not the case during earlier times. The author here affirms that telecommunication industries are deeply in need of innovative CSR strategies as they are constantly struggling between the race to retain the old loyal customers by providing better options as well as attracting new customers with lucrative offers and working towards making long time partnership with them. The research findings also show that there is however a section of customers for them innovative CSR strategies or value added services do not matter in decision making, and this section is perceived as a strong brand hostage customer segment or goodwill and trust the telecommunication company has created during the years of its service with the customers.

\section{Conclusion}

The author comes to a conclusion that CSR is important tool in telecommunication industry, which must be adopted and practiced more widely and rigorously by the companies. From the literature review it is evident that (CSR) sits at the core while service quality (SQ) is equal to customer satisfaction (CS) and that is equal to customer loyalty (CL). A very well defined CSR model does not impact the buying power of the customer but also redefines the customer retention policies and procedures, therefore (CSR) is a core towards customer loyalty. (CSR) is planned for long term and therefore needs to think of all the generations however the current CSR policies show limitations in bridging generation gaps and satisfaction. If the consumer is more in the teens the statistics can be the other way around and vice-versa for young adults and old generations. It can further be that if telecommunication industries do not come up with different innovative CSR strategies amongst them it will eventually make a tough competition amongst each other leaving very narrow choices of difference. The current network providers are not achieving the full potential of CSR, probably because of fast paced changing technologies and gadgets in the telecommunication industry. Finally, the author concludes, that the competition is tough and choices are many, it is never easy to retain the customer just on difference on pricing alone, CSR plays an important role in devising pricing, marketing, sales, sustainability, ethics, goals and responsibility. 


\section{References}

1. Dong, A., \& Li, H. (2005). Multimedia access platform for virtual learning environment. In 2005 IEEE International Conference on Electro Information Technology (pp. 6-pp). IEEE.

2. Barnard, C. (1938). The functions of the executive. Cambridge, United Kingdom: Cambridge, Mass., Harvard University Press. Retrieved from https://organizations andmarkets.files.wordpress.com/2009/09/mahoney-j-chester-barnard.pdf

3. Blery, E., Batistatos, N., Papastratou, E., Perifanos, I., Remoundaki, G., \& Retsina, M. (2009). Service quality and customer retention in mobile telephony. Journal of Targeting, Measurement and Analysis for Marketing, 17(1), 27-37.

4. Caruana, R., \& Chatzidakis, A. (2014). Consumer social responsibility (CnSR): Toward a multi-level, multi-agent conceptualization of the "other CSR". Journal of Business Ethics, 121(4), 577-592.

5. Chee, V. S. (2019). The Relationship of Service Quality, Customer. International Journal of Innovation and Business Strategy, 12.

6. CHINDA, C. C. (2020). Service quality and customer loyalty in the telecommunication industry in lagos state, Nigeria (Doctoral dissertation).

7. Clark, J. M. (1939). Social Control Of Business. (2). Chicago: Macgraw Hill \& Company Newyork \& London. Retrieved from: https://archive.org/details/in.ernet.dli.2015.52171

8. Davis, K. (1973). The case for and against business assumption of social responsibilities. Academy of Management journal, 16(2), 312-322.

9. Dominici, G., \& Guzzo, R. (2010). Customer satisfaction in the hotel industry: A case study from Sicily. International Journal of Marketing Studies, 2(2), 3-12.

10. Ghotbabadi, A. R., Feiz, S., \& Baharun, R. (2015). Service quality measurements: a review. International Journal of Academic Research in business and social sciences, 5(2), 267.

11. Gul, R. (2014). The relationship between reputation, customer satisfaction, trust, and loyalty. Journal of Public Administration and Governance, 4(3), 368-387.

12. Hapsari, R., Hussein, A. S., \& Handrito, R. P. (2020). Being Fair to Customers: A Strategy in Enhancing Customer Engagement and Loyalty in the Indonesia Mobile Telecommunication Industry. Services Marketing Quarterly, 41(1), 49-67.

13. Harazneh, I., Adaileh, M., Thbeitat, A., Afaneh, S., Khanfar, S., Harasis, A., \& Elrehail, H. (2020). The impact of quality of services and satisfaction on customer loyalty: The moderate role of switching costs. Management Science Letters, 10(8), 1843-1856.

14. Idris, A., Iftikhar, A., \& ur Rehman, Z. (2019). Intelligent churn prediction for telecom using GP-AdaBoost learning and PSO undersampling. Cluster Computing, 22(3), 72417255.

15. Kreps, T. J. (1962). Measurement of the social performance of business. The Annals of the American Academy of Political and Social Science, 343(1), 20-31.

16. Kumar, A. (2017). Effect of service quality on customer loyalty and the mediating role of customer satisfaction: an empirical investigation for the telecom service industry. Journal of Management Research and Analysis, 4(4), 159-166.

17. Imbug, N., Ambad, S. N. A., \& Bujang, I. (2018). The influence of customer experience on customer loyalty in telecommunication industry. International Journal of Academic Research in Business and Social Sciences, 8(3), 103-116. 
18. Moisescu, O. I. (2015). The impact of customers' perception of CSR on corporate brand loyalty: The case of the Romanian mobile telecom industry. Central European Business Review, 4(2), 21-30.

19. Parasuraman, A., Zeithaml, V. A., \& Berry, L. L. (1985). A conceptual model of service quality and its implications for future research. Journal of marketing, 49(4), 41-50.

20. Raf, M., \& Syarif, A. (2020). Loyalty program and its influence on customer loyalty on mobile service with customer satisfaction as a mediating variable. Journal Of Business Studies And Management Review, 3(2), 39-43.

21. Mohammed, S. S., \& Shahin, O. (2020). Service Quality Perspectives in Telecommunication Sector: Trust and Loyalty Investigation. Amazonia Investiga, 9(28), 394-403.

22. Stanisavljević, M. (2017). Does customer loyalty depend on corporate social responsibility?. Naše gospodarstvo/Our economy, 63(1), 38-46.

23. Islam, T., Islam, R., Pitafi, A. H., Xiaobei, L., Rehmani, M., Irfan, M., \& Mubarak, M. S. (2021). The impact of corporate social responsibility on customer loyalty: The mediating role of corporate reputation, customer satisfaction, and trust. Sustainable Production and Consumption, 25, 123-135.

24. Ting, H., Tan, K. L., Lim, X. J., Cheah, J. H., Ting, Q. H., \& Ting, H. B. (2020). What determines customers' loyalty towards telecommunication service? Mediating roles of satisfaction and trust. International Journal of Services, Economics and Management, 11(3), 234-255.

25. Wartick, S. L., \& Cochran, P. L. (1985). The evolution of the corporate social performance model. Academy of management review, 10(4), 758-769.

26. Yazid, A. S., Mkhiemer, I., \& Mahmud, S. M. (2020). Does Corporate Social Responsibility Activities Have a Role in Creating Customer. The Journal of Research on the Lepidoptera, 51(2), 106-123). 